\title{
O "SILENCIAMENTO" DA VOZ NEGRA FEMININA: uma análise discursiva da obra de Maria Firmina dos Reis
}

\section{The "silencing" of the female black voice: a discursive analysis of the work of Maria}

\section{Firmina dos Reis}

Nathalie de Jesus Maria Ribeiro ${ }^{1}$

Safira Ravenne da Cunha Rêgo ${ }^{2}$

RESUMO: O presente artigo tem o objetivo de analisar o "silenciamento" da escrita feminina negra na produção literária de Maria Firmina dos Reis, com enfoque em suas três principais obras - Úrsula (1859), o primeiro romance afrodescendente abolicionista de autoria feminina, o conto Gupeva (1861), com características indianistas e o conto $A$ escrava (1887), rompendo com paradigmas naturalizados. A base teórica utilizada é a Análise do Discurso de linha francesa, que representa a construção do sujeito por meio do assujeitamento e das condições de produção. Serão analisadas as condições de produção, os efeitos de sentidos, as relações de força e a memória discursiva para evidenciar o "silenciamento" da escrita do sujeito mulher negra na literatura brasileira. Dessa forma, buscou-se identificar na produção literária da escritora maranhense, considerada a primeira romancista brasileira, o "silenciamento" da mulher negra na literatura nacional, de maneira a evidenciar os efeitos raciais, de gênero e históricos-sociais, que "silenciaram" a produção literária da mulher negra no Brasil. Trata-se de uma pesquisa bibliográfica, pautada na Análise do Discurso de Michel Pêcheux (1990), centrada em autores, como Orlandi (2007; 2012). Os resultados apontam que o "silenciamento" da escrita da mulher negra na literatura brasileira deu-se por dois fatores determinantes: o de raça e o de gênero. Esses dois fatores são um acontecimento que contribuíram para a pouca representatividade de escritoras negras na literatura nacional. E, consequentemente, o racismo e o machismo contribuíram para essa invisibilidade na História, na Literatura, e na mídia brasileiras.

Palavras-chave: Literatura. Mulher negra. "Silenciamento". Discurso. Maria Firmina dos Reis.

ABSTRACT: The present article has as objective to analyze the "silencing" of black female writing in the literary production of Maria Firmina dos Reis, focusing on his

\footnotetext{
${ }^{1}$ Graduada em Letras Português e suas respectivas Literaturas de Língua Portuguesa pela Universidade Estadual do Maranhão (UEMA). E-mail: nat.ribeiro-nathalie@hotmail.com

${ }^{2}$ Graduada em Letras - Português (UFPI). Especialista em Docência do Ensino Superior (ISEPRO). Mestre em Letras - Estudos da Linguagem (UFPI). Professora efetiva da educação básica da SEDUC-MA. Professora substituta da Universidade Estadual do Maranhão (UEMA). E-mail: saffira01@hotmail.com
}

Cadernos Cajuína, V. 4, N. 1, 2019, p.208- 231.

ISSN: 2448-0916 
three major works - Úrsula (1859) the first afro-descendant abolitionist novel of female authorship, tale Gupeva (1861) with Indian characteristics and the tale A escrava (1887), breaking with naturalized paradigms. The Discourse Analysis of French line, which represents the construction of the subject through of antipersonification and the conditions of production, will be the theoretical basis used. Will be analyzed the conditions of production, the effects of senses, the relations of force and the discursive memory to evidence the "silencing" of the writing of the black woman subject in the Brazilian literature. In this way, it was sought to identify in the literary production of the writer maranhense, considered the first Brazilian novelist, the "silencing" of black women in national literature. Thus seeks out evidence the racial effects, of gender and historical-social, that "silenced" the literary production da mulher negra sujeita no Brasil. It is a bibliographical research, guided by in the Discourse Analysis of Michel Pêcheux (1990), centered on authors such as Orlandi $(2007$; 2012). The results show that the "silencing" of black woman writing in Brazilian literature, gave it to two determining factors: the one of race and the one of gender. These two factors are na hapenning which contributed to the few representativeness of black women writers in the national literature. The racism and the male chauvinist, contributed to the invisibility of the black woman subject in History, in Literature, and in the Brazilian media.

Keywords: Literature. Black woman. "Silencing”. Speech. Maria Firmina dos Reis.

\section{CONSIDERAÇÕES INICIAIS}

Sei que pouco vale este romance, porque escrito por uma mulher, e
mulher brasileira, de educação acanhada e sem o trato e
conversação dos homens ilustrados, que aconselham, que discutem
e que corrigem, com uma instrução misérrima, apenas conhecendo a
língua de seus pais, e pouco lida, o seu cabedal intelectual é quase nulo.

(REIS, 2017, p. 25)

Essa pesquisa é fruto de um amadurecimento intelectual, pautado no interesse em estudar a questão da mulher e do negro na sociedade atual, olhar que possibilitou um aprofundamento nos textos literários e na linha de pesquisa utilizada para fazer a análise do sujeito feminino negro na literatura brasileira.

É perceptível a falta de representatividade da mulher negra no cenário atual. Isso acontece, deveras, porque vivemos em uma sociedade em que o machismo e o racismo são construções históricas naturalizadas no inconsciente coletivo. Sobre 
isso, temos inscritas na sociedade um sujeito do gênero feminino, de pele escura, sem privilégios sociais, sendo oprimida pela raça, pelo gênero e pela classe social.

Basta um breve estudo sobre literatura brasileira para perceber a falta ou inexistência de mulheres negras citadas por historiadores nos estilos de época que caracterizam algum momento histórico da literatura nacional. Diversos fatores influenciaram esse apagamento: a dominação masculina, que inferioriza as mulheres intelectualmente, socialmente, economicamente etc.; a questão do letramento (LIMA; BORGES, 2014; 2018) ${ }^{3}$, que só era permitido a sujeitos homens e, quando o fazia para as mulheres, eram impostos certos limites; e a condição racial, quando se trata de mulheres negras e indígenas, que não possuem privilégios sociais, dentre outros.

Fazendo um panorama da representação de mulheres na literatura, que são visibilizadas, podemos destacar: Cecilia Meireles, Cora Carolina, Lygia Fagundes Teles, Adélia Prado. Nota-se a ausência de mulheres negras nessas representações, causando um silêncio histórico das vozes femininas negras.

A escolha do tema - $O$ "silenciamento" da voz feminina negra: Uma análise discursiva da obra de Firmina dos Reis - partiu da preocupação em evidenciar mulheres negras intelectuais dentro da literatura brasileira e com o intuito de analisar a influência dos efeitos raciais e de gênero nesse apagamento.

A opção por esse arquivo nos permitiu mostrar o sujeito mulher negra sempre evidenciada por escritores brancos, de forma estereotipada dentro da literatura - fato que permitiu a construção de uma identidade inferiorizada, cristalizada no imaginário nacional - capaz de produzir narrativas com temáticas sociais e colocar em destaque a mulher e o negro, além dos paradigmas instituídos.

Ler uma obra literária nos possibilita considerar diversos elementos propícios à sua construção - são as chamadas condições de produção e formações discursivas nas quais o sujeito está inscrito, produzindo sentidos e dizeres. $\mathrm{Na}$ Análise de Discurso evidenciamos sujeitos, memórias e imagens que ativam os sentidos e são condições para que os discursos possam ser produzidos.

\footnotetext{
${ }^{3} \mathrm{Em}$ uma análise sobre a questão do letramento da autora Maria Firmina dos Reis, Lima; Borges (2018, p. 203) afirmam que: "A condição de letrada, no sentido de saber ler e escrever, ou seja, ser alfabetizada e ter o domínio do código escrito formal faz com que Maria Firmina dos Reis, em Úrsula, imprima uma posição política e ideológica no meio social, na medida em que se utiliza da variedade do código linguístico, para construir um projeto do dizer, no qual fica evidente seu nível de letramento e a importância desse fenômeno na construção do gênero e da raça".
} 
O interesse pela Análise do Discurso (AD), em específico, o discurso literário, deu-se pela historicidade da língua e do discurso, e pela compreensão e construção das condições ideológicas do sujeito. Dessa maneira, evidencia-se o discurso literário num panorama, social, histórico e político, mostrando no arquivo, produtos da realidade.

\section{UMA ABORDAGEM GERAL DA ANÁLISE DO DISCURSO}

A AD teve sua origem na França na década de 1960, duplamente articulada entre Michel Pêcheux e Jean Dubois, seu surgimento foi marcado por questões políticas, culturais e históricas presentes no meio social. A produção de sentidos é provocada pelo equívoco, pela memória, pelas condições de produção, pelas relações de força e pelo esquecimento, só assim, os discursos são produzidos.

A constituição da AD nos anos 60 se deu no meio de questões criadas pela relação entre três grandes áreas disciplinares que romperam, simultaneamente, com acontecimentos do século XIX: a Linguística, o Marxismo e a Psicanálise. O legado da Linguística se deu pela opacidade da linguagem: "ela tem seu objeto próprio, a língua, e esta tem sua ordem própria" (ORLANDI, 2007, p. 19). Segundo a autora:

\footnotetext{
Esta afirmação é fundamental para a Análise do Discurso, que procura mostrar que a relação linguagem/pensamento/mundo não é unívoca, não é uma relação direta que se faz termo-a-termo, isto é, não se passa diretamente de um a outro. Cada um tem sua especificidade. (ORLANDI, 2007, p. 19)
}

A linguagem, a história, o sujeito e a ideologia são passíveis de interpretação e dotados de sentidos, "de um lado os sujeitos e os sentidos se estabelecem; de outro, eles se estabilizam, se cristalizam, permanecem" (ORLANDI, 2007, p. 10). Na $A D$, a manifestação da linguagem é pelo simbólico, pelo equívoco, pela memória e pela historicidade, sempre comprometido com os sentidos e o político.

A AD trata do discurso, como "palavra em movimento, prática da linguagem: com o estudo do discurso observa-se o homem falando" (ORLANDI, 2007, p. 15). Ela procura compreender a "língua fazendo sentido", as condições de produção, os efeitos de sentidos, o interdiscurso, o esquecimento, as falhas, os equívocos que torna o sujeito ideológico e simbólico, constituindo várias maneiras de significar. 
O discurso funciona regulamente, não há possibilidades de oposições entre o "social e o histórico, o sistema e a realização, o subjetivo ao objetivo, o processo ao produto". Dessa maneira,

[‥] diremos que não se trata de transmissão de informação apenas, pois, no funcionamento da linguagem, que põe em relação os sujeitos e os sentidos afetados pela língua e pela história, temos um complexo processo de constituição desses sujeitos e produção de sentidos e não meramente transmissão de informação. (ORLANDI, 2007, p. 21)

Problematizar discursos é essencial e transformador, assim, questionar os discursos literários abre um leque de possibilidades de interpretação, com uma ótica para as condições de produção, o esquecimento, o apagamento, os efeitos de sentidos, as relações de força e para o interdiscurso que reflete na constituição, construção e na institucionalização do sujeito inscrito na História. Assim, neste estudo, a trajetória literária de Maria Firmina dos Reis, primeira romancista maranhense afrodescendente, é analisada na perspectiva da $A D$, uma vez que é afetada pelo real da língua e pela historicidade.

Evidenciando aspectos como a construção do machismo e do racismo, com um olhar atento sobre o papel do sujeito mulher negra na sociedade brasileira do século XIX, os escritos de Firmina expõem questões raciais e de gênero, trazendo uma nova abordagem para o negro, diferentemente, da construída por escritores brancos. O enfoque da análise questiona o "silenciamento" da voz feminina negra na literatura brasileira.

No arquivo em foco, que trata de um breve apanhado da vida e obra de Firmina, com destaque para sua Opus Magnum Úrsula, publicada em 1859 e que permaneceu em silêncio por 116 anos, e para seus contos Gupeva, publicado em 1865 e $A$ escrava, publicado em 1887, projetando especificamente o sujeito mulher negra como escritora. Os sentidos estão inscritos nas formações discursivas presentes nas condições de produção que constituem a trajetória da escritora.

Ao refletir sobre o discurso literário do arquivo utilizado, percebe-se que há nele relações de força - "o lugar a partir do qual fala o sujeito" - que interferem na constituição dos sentidos presentes na escrita do sujeito mulher negra. Nota-se que questões raciais e de gêneros são instituídas no imaginário coletivo acerca do papel da mulher negra na sociedade brasileira. 
Há uma necessidade de entendimento das relações de poder presente na sociedade, as quais determinam sentidos e funções do sujeito ideologicamente afetado. O poder representa uma imposição, que organiza a sociedade hierarquicamente. Ademais, Foucault (1980, p. 187) diz que "entre cada ponto do corpo social, entre homem e mulher, entre membros de uma família, [...] entre cada um que sabe e cada um que não sabe, existem relações de poder".

Foucault (2014) evidencia o poder como algo essencial para manter a ordem social, pois, sem ele não há organização estrutural. Além disso, o autor afirma:

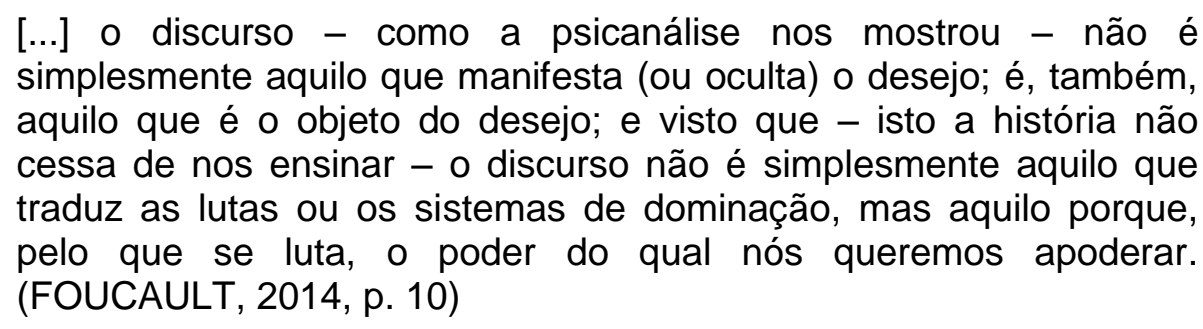

Ao analisar esse "silenciamento" do sujeito feminino negro, faz-se uma associação da perspectiva discursiva com a literatura, com enfoque na herança literária de Maria Firmina dos Reis. O foco da análise, é evidenciar como efeitos raciais, de gênero e histórico-sociais, interferiram no apagamento da escritora, assim como os efeitos de sentidos produzidos pelo seu trabalho literário. A partir dos dizeres e do lugar de enunciação, é possível construir um sujeito concreto questionado pela ideologia e pela historicidade.

É nesse contexto patriarcal que a mulher negra ousa escrever sobre questões abolicionistas, e projeta o negro sobre uma nova ótica, diferentemente das ditas por escritores brancos. Firmina é, logo, uma mulher negra, que constrói um discurso envolto por uma cortina de silêncio, e que está sendo rompido gradativamente.

\section{O SILÊNCIO DA VOZ DE MARIA FIRMINA DOS REIS}

No silêncio, o sentido se faz em movimento, a palavra segue seu curso, o sujeito cumpre a relação de sua identidade (e da sua

diferença).

(ORLANDI, 1995, p. 38) 
Maria Firmina dos Reis, primeira escritora maranhense e primeira romancista afrodescendente do século XIX, nasceu em São Luís, capital do Maranhão no dia 11 de outubro de 1825. Registrada como filha de Leonor Felipe dos Reis e João Pedro Esteves, passou sua infância na companhia de sua vó, mãe e suas duas únicas amigas, Balduinna e sua irmã Amália Augusta do Reis. Aos cinco anos de idade, mudou-se para a Vila de São José de Guimarães, município de Viamão para morar com sua tia, que possuía uma melhor situação financeira, o que foi de grande importância para sua formação.

Firmina era prima do jornalista, escritor e gramático Francisco Sotero dos Reis, este, "a quem deve sua cultura, como afirma em diversos poemas" (LOBO, 1993, p. 224). Mulher negra que viveu em um período marcado por opressões raciais, de gênero e sociais, e teve a ousadia de evidenciar o negro com um olhar diferente de outras construções ideológicas, até então, mostrados pelo olhar do branco.

Com vinte e dois anos de idade, Firmina torna-se a primeira professora aprovada em um concurso público, na então cidade de Guimarães para ocupar a Cadeira de Instrução Primaria. Em 1881, aposenta-se e funda a primeira escola mista e gratuita do estado do Maranhão, no vilarejo de Maçaricó, com o objetivo de ajudar os filhos dos lavradores da região (MORAIS FILHO, 1975). Segundo Telles (1987, p. 412):

Um ano antes de se aposentar, com trinta e quatro anos de magistério público oficial, Maria Firmina dos Reis fundou, a poucos quilômetros de Guimarães, em Maçaricó, uma aula mista e gratuita para alunos que não pudessem pagar. Estava então com 54 anos. Toda manhã, subia em um carro de bois, para dirigir-se a um barracão de propriedade de um senhor de engenho, onde lecionava para as filhas do proprietário. Levava consigo alguns alunos, outros se juntavam. Um experimento ousado para a época.

Nota-se que a escritora maranhense foi pioneira em vários setores dentro da sociedade, contribuindo para o desenvolvimento social no meio que estava inserida. A fundação da escola mista causou polêmica dentro da sociedade maranhense, por que não era comum, meninas e meninos estudarem juntos. Por conta do escândalo causado dentro da Atenas Brasileira, a escola funcionou por dois anos e meio, e depois, a professora foi obrigada a suspender as aulas. Apesar disso, Firmina continuou a ministrar as aulas para crianças da região. 
Morais Filho (1975), afirma que Firmina criou uma escola que foi uma revolução social pela educação e uma revolução educacional pelo ensino o seu pioneirismo subversivo de 1880. Ela rompeu um paradigma social para a época, mudando "a ordem educacional vigente, ao quebrar o cânone moral oficializado, que segregava os sexos em aulas separadas" (MORAIS FILHO, 1975, s.p).

A escritora possui uma vasta produção intelectual de grande importância para a literatura brasileira, mas devido suas condições de gênero, raciais e sociais permaneceu em "silêncio" por 116 anos. "Silencio" este, que está sendo rompido devido ao grande número de pesquisadores interessados em ecoar a voz "silenciada" de Maria Firmina dos Reis.

A autora publicou romances, crônicas e poesias e também, atuou na impressa maranhense no período oitocentista. A primeira obra de Firmina foi publicada em São Luís, pela Tipografia do Progresso. O romance Úrsula, publicado no ano de 1859, com uma temática abolicionista que evidenciava o sujeito negro de uma perspectiva diferente do que já havia sido abordado.

A escritora viveu em um período onde as condições de gênero e raciais eram marginalizadas socialmente. A mulher do século XIX, era submissa ao homem e não tinha liberdade de escolha, sem nenhum direito, ou com direitos limitados. Firmina, mulher negra e de educação simplória, viveu em um período onde as campanhas abolicionistas estavam a todo vapor. Foi a primeira mulher a escrever sobre questões abolicionistas, contribuindo para a literatura afrodescendente. Diferentemente de escritores brancos, como Bernardo Guimarães, que publicou o romance $A$ escrava Isaura, recebido de forma positiva pela crítica e mostrava a escravidão de forma implícita, em Úrsula, o negro é evidenciado sobre uma nova ótica, uma visão mais humana e uma denúncia da real face da escravidão.

Ao longo de sua vida publicou diversos contos, poesias, crônicas em jornais do Maranhão, como Publicador Maranhense, A verdadeira Marmota, O Jardim dos Maranhense e Ethos da Juventude, entre outros (MORAIS FILHO, 1975). Após a abolição, Firmina compõe a letra e música do "Hino da Libertação dos escravos".

Foi no ano de 1962 que o primeiro romance abolicionista de autoria feminina, intitulado Úrsula é encontrado pelo pesquisador e bibliófilo Horácio de Almeida, em meios a um lote de livros usados comprados por ele. Firmina não grava seu nome na primeira edição que vem com o heterônimo "uma maranhense", isso dificultou as pesquisas de Horácio Almeida. Para Lobo (1993), o exemplar Cadernos Cajuína, V. 4, N. 1, 2019, p.208- 231.

ISSN: 2448-0916 
encontrado pelo bibliófilo "é o único exemplar remanescente" da edição de 1859. E foi graças ao Dicionário de Pseudônimos Regionais, que após longa pesquisa, ele conseguiu a identificação da autora. Almeida, por muito anos, foi o único que possuía a Opus Magnum de Firmina.

Foi no ano de 1975, que sai pela Gráfica Olímpica a edição fac-similar de Úrsula, na cidade do Rio de Janeiro, com o prefácio do pesquisador Horácio Almeida. Esse foi o início do rompimento do "silêncio" da primeira escritora afrodescendente que abordava temas abolicionista na referida obra, que mostrava a real face da mulher e do negro.

Foi nesse mesmo ano, que o historiador maranhense Nascimento Morais Filho, organiza e publica Maria Firmina: fragmentos de uma vida, que contou com o governo do Maranhão para a sua edição. Nesse livro, Morais Filho reuniu um acervo riquíssimo sobre a vida e obras da escritora. Além de anexos, entrevistas, composições e publicações em jornais. Em 1988, Luiza Lobo lança a terceira edição do romance popular brasileiro Úrsula. Essa cronista e também professora vem contribuindo para o fim desse apagamento literário e histórico.

Maria Firmina dos Reis faleceu aos 92 anos de idade, na então Cidade de Guimarães, pobre e cega, onde vivia com seu filho adotivo, Leude Guimarães. Com isso, mais tarde Leude muda-se para São Luís, onde seu quarto é assaltado e uma boa parte da documentação da escritora se perde, fato que dificulta as pesquisas realizadas a respeito de Firmina. Além das questões de gênero, raciais e sociais, as falhas e os equívocos da língua também foram responsáveis para essa pouca ou quase nenhuma visibilidade de Maria Firmina dos Reis.

A escritora também foi ignorada por grandes historiográficos literários, como Sílvio Romero e José Verissimo. Nenhum deles, a menciona, exceto Sacramento Blake. O romance Úrsula está ausente das páginas de Alfredo Bossi, Alfredo Candido, Antônio Coutinho, Lúcia Miguel Pereira, Nelson Werneck Sodré, entre outros. O fato de Firmina não ter sido evidenciada em manuais de literatura, ocasionou esse apagamento que durou mais de cem anos. A escritora viveu em um momento onde a mulher era considerada inferior intelectualmente em relação aos homens, e o negro também era inferiorizado. A ousadia de uma mulher negra em usar sua pena para denunciar o real da história referente a escravidão, poderia ter causado esse "silenciamento". 


\section{A CONSTRUÇÃO DE UM NOVO DIZER - "ROMANCE ORIGINAL BRASILEIRO": "ÚRSULA" (1859)}

A obra Úrsula, primeiro romance afro-brasileiro abolicionista de autoria feminina, foi publicado pela Tipografia Progresso no ano de 1859, na cidade de São Luís, pela escritora Maria Firmina dos Reis. A autora não grava seu nome nessa primeira edição, inscreve apenas o termo "uma maranhense", fato que irá dificultar a atribuição de autoria para Firmina e contribui para o silêncio histórico da obra.

O texto que faz parte da fase ultrarromântica, inaugura na literatura a representação do negro na condição de escravo, criticando fortemente o regime escravista e traz uma crítica a condição submissa da mulher no século XIX. Sobre isso, é importante ressaltar que a escritora viveu em um momento que a mulher era considerada inferior intelectualmente. No romance, o negro e a mulher são evidenciados como vítimas desse sistema opressor, situação vivida por Firmina, mulher negra e pobre.

Numa época onde o machismo e o racismo dominavam todo a estrutura social, ser mulher negra, pobre e escritora, foi um ato de ousadia. O romance Úrsula veio para romper com a construção de estereótipos da mulher e do negro. Essas problemáticas, que se distanciou dos dizeres já impostos, causou um estranhamento nos leitores. A obra contém XX capítulos com características ultrarromânticas, pautada em denúncias sociais. Nosso arquivo contempla elementos de ordem política, social e histórica, além de tornar significativo o sujeito negro e feminino frente à constituição de sentidos.

Sobre o teor político nos discursos, Courtine $(1999$, p. 12) ressalta que:

Não se faz a mesma Análise do Discurso político, quando a comunicação política consiste em comícios reunindo uma multidão em torno de um orador e quando toma a forma de talk-shows televisivos aos quais cada um assiste em casa. Também não se faz a mesma Análise do Discurso independentemente dos preconceitos, das compartimentalizações sociais e ideológicas, das polêmicas antigas ou recentes; tudo isso exerce suas restrições sobre o discurso das ciências humanas, na escolha de seus temas, na definição dos objetivos, na produção de recortes forma.

$\mathrm{Na}$ obra existem denúncias, preconceitos, crueldade e limitações. No entanto, a construção dos personagens negros e femininos é dotada de princípios e 
de ressignificação do perfil dos mesmos na literatura. Houve uma quebra de paradigma da imagem que vinha sendo construída para o sujeito negro e feminino no Brasil. Um olhar vindo de uma mulher negra, possuidora do real da história para evidenciar fatos, alheios aos leitores, que já possuíam no seu imaginário uma construção do negro e da mulher no seu inconsciente.

No prólogo da obra, a autora afirma saber que "pouco vale este romance, porque escrito por uma mulher, e mulher brasileira, de educação acanhada e sem o trato e conversação dos homens ilustrados" (REIS, 2017, P. 25). Úrsula traz em sua narrativa uma visão positiva do negro sem preconceitos raciais e estereótipos comuns no seu tempo. Firmina levanta sua voz através do que ela chamou de "mesquinho e humilde livro".

O romance aborda uma trágica história de amor entre os personagens Úrsula e Tancredo e faz fortes denúncias ao sistema escravocrata da época. Uma narrativa que tem um final diferente dos romances da época, marcados por ilusões, decepções e desencontros. Temos em evidência a jovem Úrsula, que é envolvida em uma tragédia familiar, aprisionada por um tio, que idealiza um amor pela sobrinha, em uma fazenda falida no Maranhão. Na trama, sua mãe se encontra doente e depende dos cuidados da filha, Tancredo, o herói romântico, é assassinado pelo tio da sua amada, que tem planos de desposá-la. Há suspeitas que Fernando $\mathrm{T}$, teria matado e roubado seu pai, fato que atormenta a heroína por toda o desenrolar da novela. O cenário social do enredo é a escravidão.

É nesse cenário escravocrata, que surge Túlio, mãe Susana e Antero, os personagens negros antagonistas que são evidenciados por uma nova ótica, retratando a escravidão sem disfarces. No romance, Túlio é mostrado como vítima, não como um carrasco, sua revolta permanece em silêncio, não tem armas para afrontar o poder dos senhores. A autora usou de comportamentos cristãos para construir o personagem Túlio, com uma intenção de pregar suas ideias.

Senhor Deus! Quando calará no peito do homem a tua sublime máxima - ama a teu próximo como a ti mesmo - e deixará de oprimir com tão repreensível injustiça ao seu semelhante!... a aquele que também era livre no seu país... aquele que é seu irmão?! E o mísero sofria; porque era escravo, e a escravidão não lhe embrutecera a alma; porque os sentimentos generosos, que Deus Ihe implantou no coração, permaneciam intactos, e puros como sua alma. Era infeliz; mas era virtuoso; e por isso seu coração enterneceu-se em presença da dolorosa cena, que se lhe ofereceu à vista. (REIS, 2017, p. 32) 
O discurso literário de Firmina possibilitou mostrar a voz do negro através de sua escrita, como uma estratégia para abordar assuntos raciais de uma forma honesta, pautadas em suas vivências. A autora ousa em dar voz para uma personagem secundária negra, para que ela contasse as reais questões da escravidão, sob um olhar do escravo, Preta Susana, que descreve sua vida na África, terra onde tinha a verdadeira liberdade. Ela faz um relato através da voz e da memória às condições da trajetória dos negros até chegar no Brasil.

\begin{abstract}
Ainda não tinha vencido cem braças de caminho, quando um assobio, que repercutiu nas matas, me veio orientar acerca do perigo iminente, que aí me aguardava. E logo dois homens apareceram, e amarraram-me com cordas. Era uma prisioneira - era uma escrava! Foi embalde que supliquei em nome da minha filha, que me restituíssem a liberdade: os bárbaros sorriam-se de minhas lágrimas, e olhavam-me sem compaixão [...] Meteram-me a mim e a mais trezentos companheiros de infortúnio e de cativeiro no estreito e infecto porão de um navio. Trinta dias de cruéis tormentos, e de falta absoluta de tudo quanto é necessário à vida passamos nessa sepultura até que abordamos as praias brasileiras. Para caber a mercadoria humana no porão fomos amarrados em pé para que não houvesse receio de revolta, acorrentados como animais ferozes das nossas matas que se levam para recreio dos potentados da Europa. (REIS, 2017, p. 102-103)
\end{abstract}

Em um diálogo que aconteceu entre Susana e Túlio, recém-alforriado, ela questiona essa impossibilidade dessa tal "liberdade" em terras escravistas. Para Susana, o ideal de "liberdade", só faz sentido do lugar em que foi violentamente, arrancada.

- Túlio, - continuou - não sabes quanto sofro quando recordo-me de que nossa querida menina vai tão breve ficar só no mundo! Só, Túlio! Quem a acompanhará? quem poderá consolá-la! Eu? Não. Pouco poderei demorar-me neste mundo. Meu filho, acho bom que não te vás. Que te adianta trocares um cativeiro por outro! E sabes tu se ao o encontrarás melhor? [...] - Oh! Quanto a isso não, mãe Susana tornou Túlio - [...]. Não troco cativeiro por cativeiro, oh, não! troco escravidão por liberdade, por ampla liberdade! [...] - Tu! Tu livre? ah não me iludas! - exclamou a velha africana abrindo uns grandes olhos. Meu filho, tu és já livre?... (REIS, 2017, p. 100-101)

O escravo alforriado Túlio, traz no seu inconsciente que a escravidão se limita apenas ao corpo. Suas ideias deixam claro que sua alma é propriedade dele, 
que jamais poderia ser escravizada e que sonhava com a liberdade do seu corpo e de sua raça.

[...] Oh! A mente isso sim ninguém a pode escravizar! Nas asas do pensamento o homem remonta-se aos ardentes sertões da África, vê os areais sem fim da pátria e procura abrigasse debaixo daquelas árvores sombrias do oásis, quando o sol queima e o vento sopra quente e abrasador: vê a tamareira benéfica junto à fonte, que the amacia a garganta ressequida: vê a cabana onde nascera, e onde livre vivera! [...] porque a alma está encerrada nas prisões do corpo! Ela chama-o para a realidade, chorando, e o seu choro, só Deus compreende! Ela, não se pode dobrar, nem lhe pesam as cadeias da escravidão; porque é sempre livre, mas o corpo geme, e chora; porque está ligada a ele na vida por laços estreitos e misteriosos. (REIS, 2017, p. 44)

Em Úrsula, Maria Firmina dos Reis evidencia a escravidão de uma forma atualizada. Através da obra literária, a autora aborda questões políticas, sociais, raciais e de gênero, ousa em uma sociedade cheia de injustiças sofridas, principalmente por mulheres e negros. A obra passou 116 anos esquecida, justamente por ser escrita por uma mulher negra e pobre em uma sociedade em que o racismo e o machismo são uma construção social, fixadas no inconsciente coletivo.

\section{DESCOLAMENTO INDIANISTA - "GUPEVA" (1861)}

O conto Gupeva, publicado em 1861, no jornal O Jardim dos Maranhenses, traz no seu enredo, a imagem da mulher indígena. Nos anos de 1863 e 1865, na devida ordem, no jornal Porto Livre e no jornal literário Ethos da Juventude, este conto foi republicado, tendo deixado perceptível que a narrativa com temática indianista atingiu sucesso no período, tendo em vista as republicações. É evidenciado também, pelo historiador Nascimento Morais Filho, em seu livro Maria Firmina: fragmentos de uma vida.

Gupeva foi apresentado no jornal literário O Jardim dos Maranhenses, com a seguinte nota:

Existe em nosso poder, com destino a ser publicado no nosso jornal um belíssimo e interessante ROMANCE, primoroso trabalho da nossa distinta provinciana, a Exma. Sra. D. Maria Firmina dos Reis, 
professora pública da Vila de Guimarães; cuja a publicidade tencionamos dar princípio do ํo 25 em diante.

Garantimos ao público a beleza da obra e pedimos-lhes a sua benévola atenção. A pena da Exma. Sra. D. Maria Firmina dos Reis e nós já é entre nós conhecida; e convém muito acalmá-la a não desistir da empresa encetada. Esperamos, pois a vista das razões expedidas, que nossas súplicas sejam atendidas, afiançando que continuaremos no nosso propósito: sempre defendendo o belo e amável sexo - quando injustamente for agredido. Saluz et paz. ${ }^{4}$

A nota mostra que a escritora era bem conhecida no período de publicação do conto indianista. No mesmo ano de publicação do romance, 1861, Firmina participa de uma coletânea poética Parnaso Maranhense, organizada por Gentil Homem de Almeida Braga, sendo importante ressaltar que seus textos já circulavam dentro da província maranhense do século XIX.

A imagem da mulher representada no conto Gupeva é construída de maneira diferenciada, se compararmos a outros textos indianistas do período, possivelmente conhecidos por Maria Firmina, em especial o texto de Frei José de Santa Rita Durão (DURÃO, 2003), Caramuru, de 1781. Firmina traz no seu conto os personagens Gupeva, Caramuru e Paraguaçu, personagens do texto de Durão. $O$ enredo narra os encontros e os desencontros de dois povos distintos: europeu e indígena. Certamente, Gupeva teve influência do poema do seu conterrâneo Gonçalves Dias, I-Juca Pirama, Últimos Cantos (DIAS, 2002), publicado em 1851.

O cenário onde se desenrola o enredo da narrativa é a Bahia, espaço em que se desenvolveu a "verdadeira" história de Caramuru. O texto conta a história de um índio de nome, Gupeva, pai da índia Épica, que se apaixona pelo marinheiro francês Gastão. Gupeva conta a trágica história de uma índia que faz uma viagem com Paraguaçu e Caramuru para a França. Épica quando retorna para a América, casa-se com Gupeva e revela que foi seduzida pelo conde de... e não é mais virgem. Mesmo envergonhado, o índio cria a criança, que é filha do francês e a batiza com o nome da mãe, Épica. No ápice da trama, Gastão descobre que sua amada é filha de seu pai, o conde de... e, dessa forma, seu amor era pecado. Gupeva, ao descobrir isso, mata Gastão e Épica, a filha também acaba morrendo, assim como Gupeva.

\footnotetext{
4 Jornal o Jardim dos Maranhenses, periódico semanário. Literário, moral, crítico, receptivo. 29 de setembro de 1861. O conto (ROMANCE) começa a ser publicado em 13 de outubro de 1861. BPBL, Hemeroteca.
} 
Maria Firmina constrói, através dessa narrativa trágica, uma imagem fascinante da mulher indígena e da pátria, fato já construído sob a pena dos poetas românticos da sociedade brasileira. Nota-se que os escritos de Firmina são carregados de memória e sentidos que atravessam o texto. Ela abordou os temas que escritores, como Gonçalves Dias e José de Alencar trouxeram nos seus textos, porém, no seu conto Gupeva, ela constrói um ideal de uma sociedade verdadeiramente brasileira.

\section{CONTO "A ESCRAVA" (1887) - O FORTALECIMENTO DO DIZER ABOLICIONISTA}

A Escrava, obra publicada em 1887, meses antes da promulgação da Lei Áurea, simboliza o ápice do desenvolvimento intelectual de Maria Firmina do Reis. A escritora estava com sessenta e dois anos de idade, e, diferentemente de quando escreveu sua Opus Magnum Úrsula, era dotada de conhecimento e acompanhava discussões do código vigente da época.

No conto, percebemos uma escritora mais informada da situação dos escravos na sociedade oitocentista brasileira. Além disso, traz uma nova abordagem para a mulher negra, que é sempre descrita de forma inferiorizada e objetificada por escritores brancos. A escritora evidencia no seu enredo, uma quebra de paradigma a respeito da construção do perfil da mulher negra, não temos mais um sujeito feminino negro estereotipado.

Foi publicado em São Luís, no terceiro número da Revista Maranhense, com duras críticas ao regime escravocrata, evidenciando a forma cruel como os escravos eram tratados. Tendo como ponto central os dramas vividos pela escrava Joana, que fugiu da fazenda que vivia, contados ao longo da trama por "uma senhora", Firmina, logo, põe-se a debater as questões políticas e sociais daquela época, mas, sobretudo, a abolição da escravatura.

O início do conto é uma conversação que aborda diversos assuntos referentes ao "elemento servil", por uma senhora que não é identificada em toda a narrativa: 
sentimentos escravocratas, no presente século, no século dezenove! A moral religiosa, e a moral cívica aí se erguem, e falam bem alto esmagando a hidra que envenena a família no mais sagrado santuário seu, e desmoraliza, e avilta a nação inteira! Levantai os olhos ao Gólgota, ou percorrei-os em torno da sociedade e dizei-me: Para que se deu em sacrifício, o Homem Deus, que ali exalou seu derradeiro alento? Ah! Então não é verdade que seu sangue era o resgate do homem! É então uma mentira abominável ter esse sangue comprado a liberdade!? E depois, olhai a sociedade... Não vedes o abutre que a corrói constantemente!... Não sentis a desmoralização que a enerva, o cancro que a destrói? (REIS, 2017. p. 193)

Notamos que a escritora escolheu uma personagem feminina para falar sobre a escravidão, e o discurso da "senhora" sem nome é carregado de ideais abolicionistas. O conto foi publicado em um momento histórico afetado por acontecimentos que refletem na condição do negro na sociedade brasileira. A autora usa de argumentos religiosos para convencer outrem da crueldade da escravidão.

A "senhora" (que não é nomeada em toda a narrativa) narra a trajetória de Joana, uma escrava liberta aos cinco anos de idade, viveu apenas dois anos de "liberdade" e logo, foi "reescravizada". Insatisfeita com seu triste destino, sempre estava em fuga, devido à violência do sistema escravocrata vigente, e pelo trauma provocado pela separação dos seus filhos gêmeos - de oito anos de idade, Carlos e Urbano, que foram vendidos e levados para o Rio de Janeiro - causa da sua loucura. Notamos que sua loucura é causada por questões subjetivas e objetivas, a que foi submetida. Ou seja, a violência, tanto psicológica, como física, Ihe deixou marcas que lhe causaram traumas, tanto a perdas dos dois filhos, quanto as sequelas deixadas pelo cativeiro, pelos castigos e pelo regime escravista.

Na sua última fuga, "uma senhora" Ihe oferece ajuda e a esconde do feito, em seguida seu filho Gabriel chega à sua procura. A "senhora" oferece proteção para ambos e os leva para sua casa, onde passa a escondê-los. É neste lugar que se desenrola a narrativa: ocorre, ao mesmo tempo, a vida e morte da escrava Joana, e a libertação do seu filho Gabriel, que é comprado pela senhora. Firmina objetiva com esse conto, denunciar as injustiças sociais e as condições do negro na sociedade no auge da campanha abolicionista, além de descrever as condições opressivas e sub-humanas do negro e da mulher no cenário nacional.

Dessa forma, a escrava Joana narra todas suas memórias e em seguida morre de exaustão. Abaixo um fragmento do conto que ilustra essa passagem: 
- Deixa concluir, meu filho, antes que a morte me cerre os lábios para sempre... deixa-me morrer amaldiçoando os meus carrascos.

- Por Deus, por Deus, gritei eu, tornando a mim, por Deus, levem-me com meus filhos!

- Cala-te! Gritou meu feroz senhor. - Cala-te ou te farei calar.

- Por Deus, tornei eu de joelhos, e tomando as mãos do cruel traficante: meus filhos! Meus filhos!

Mas ele dando um mais forte empuxão, e ameaçando-os com o chicote, que empunhava, entregou-os a alguém que os devia levar... Aqui a mísera calou-se; eu respeitei o seu silêncio que era doloroso, quando lhe ouvi um arranco profundo, e magoado:

Curvei-me sobre ela: Gabriel ajoelhou-se, e juntos exclamamos:

- Morta!

Com efeito tinha cessado de sofrer. O embate tinha sido forte demais para suas débeis forças. (REIS, 2017, p. 204)

Firmina evidencia a mulher e o negro, ousando e quebrando paradigmas que haviam sido impostos e que perpetuam até hoje, por escritores brancos. Apesar, da escritora ter um grande reconhecimento nesse período, contribuindo assiduamente para a literatura nacional, seus escritos caíram no esquecimento. Fatores que influenciarem esse silêncio histórico, que buscamos romper nos dias atuais, são o racismo, machismo e questões sociais, uma vez que não era comum uma mulher, negra e pobre fazer denúncias em uma sociedade patriarcal e racista.

\section{MEMÓRIA DISCURSIVA}

Na memória discursiva o sujeito é atravessado pelo real da língua e pelo real da história, logo é doado de significado. Para Orlandi (2007, p. 53),

O sujeito significa em condições determinadas.... reclamam sentidos, e também por sua memória discursiva, por um saber/poder/dever dizer, em que os fatos fazem sentidos por se inscreverem em formações discursivas que representam no discurso as injunções ideológicas.

Os dizeres estão sendo atualizados constantemente, isso acontece através da memória discursiva e interdiscurso. A língua é construída através de mudanças históricas, por estar ligada particularmente ao indivíduo que está inserido em um meio social, se relacionando com outros indivíduos, produzindo discursos já 
mencionados anteriormente e, posteriormente, em diversas formações discursivas. Conforme Orlandi (2012, p. 21):

\begin{abstract}
A Análise do Discurso é a disciplina que vem ocupar o lugar dessa necessidade teórica, trabalhando a opacidade do texto e vendo nesta opacidade a presença do político, do simbólico, do ideológico, o próprio fato do funcionamento da linguagem: a inscrição da língua na história, para que ela signifique.
\end{abstract}

A análise em questão tem na produção do seu discurso uma carga histórica, política e social, determinado pelas condições de produção, que o sujeito, atravessado pela ideologia, está inscrito e carregado de sentidos e dizeres já tidos e construídos. Sobre isso, Pêcheux aborda o termo "memória discursiva, que Orlandi (2007, p. 31), reforça, como "o saber discursivo que torna possível todo dizer e que retorna sob a forma do pré-construído".

Lopes (2009) reitera que os discursos são inscritos na linguagem e na historicidade, a partir da produção de sentidos. As formações discursivas, por sua vez, são construídas através da história, sendo possível o discurso significar. Assim, para que a linguagem reclame sentidos é tratada como incompletude, como condição necessária para significar. Para Orlandi (2007, p. 52), "nem os sujeitos nem os sentidos estão completos, já feitos, constituídos definitivamente. [...] Essa incompletude atesta a abertura do simbólico, pois a falta é também o lugar do possível". A falha, o equívoco, o esquecimento, o inconsciente, a ideologia e a linguagem são responsáveis pelo funcionamento dos discursos, dos sujeitos e dos sentidos.

Nas diversas formações discursivas, os discursos, os sujeitos e os sentidos estão incompletos, isso possibilita um leque de interpretações e (re) significações. Nessa visão, diz Orlandi (2007, p. 52), que devemos nos atentar "a literalidade em relação ao processo discursivo com suas condições". Pois,

Se a ilusão do sentido literal - ou do efeito referencial, que representa a relação imanente entre palavra e coisa, considerando que as "estratégias" retóricas, "manobras" estilísticas não são constitutivas da representação da realidade determinada pelos sentidos de um discurso - faz o sujeito ter a impressão da transparência, é tarefa do analista de discurso expor o olhar leitor à opacidade do texto, como diz M. Pêcheux (1981), para compreender como essa impressão é produzida e quais seus efeitos. (ORLANDI, 2007, p. 52) 
Na produção dos discursos e sentidos, devemos nos atentar para a posição do sujeito e sua capacidade de antecipação, isso é analisado em relação aos dizeres já ditos. Assim, a constituição do sujeito, através da linguagem, da história e da política provoca essa antecipação, descentralizando o sujeito carregado de ideologia e significados.

Contudo, essa antecipação deve ser abordada na trajetória intelectual de Maria Firmina dos Reis, com enfoque em suas três principais obras - Úrsula (1859), o primeiro romance afrodescendente abolicionista de autoria feminina, conto Gupeva (1861), com características indianistas e o conto $A$ escrava (1887), escrito um ano antes da abolição da escravatura -, narrativas que abordam a mulher e o negro sob uma nova perspectiva, rompendo com paradigmas naturalizados.

Dessa forma, são analisadas as condições de produção do sujeito feminino negro dentro da literatura brasileira. O discurso de Firmina aponta para outros já evidenciados, mas por homens e na sua maioria brancos, com isso tiveram mais visibilidade. Para compreendermos o real da história que atravessa a trajetória literária da autora, recorremos à materialidade de outras obras e escritores que evidenciam a forma e o conteúdo. A que nos interessa é a de um autor já consagrado, diferentemente da autora, trata-se de um homem, branco, nascido no mesmo ano de Firmina e que publicou a obra que o consagrou, dezesseis anos após a publicação do primeiro romance da escritora: Bernardo Guimarães, com A escrava Isaura.

Abordamos esse nome, pois a formação discursiva está naturalizada no sentido histórico e no interdiscurso dos sujeitos analisados. Essa relação da memória discursiva é feita usando a trajetória intelectual do autor, suas características literárias e sua questão como sujeito homem no momento histórico em que é inscrito, com enfoque para uma das suas principais obras, essa com características semelhantes à da produção da escritora.

De acordo com Nunes (2008, p. 83), "uma obra passa a ser um 'documento' na medida em que ela é historicizada, ou seja, na medida em que ela se torna um objeto de um saber documental. O texto nomeia data, seleciona objetos e traça percursos".

O momento histórico a que os escritores pertencem e publicaram seus textos é um lugar em que o gênero feminino era subserviente ao gênero masculino. 
Ambos possuem textos de caráter denunciativo do regime escravocrata, que estava no auge, assim, Firmina, e o sujeito feminino negro em questão, tem influência do processo abolicionista da época, ela traz um novo perfil para o negro e para a mulher, ademais, Bernardo Guimarães mesmo seu texto sendo afetado por características abolicionista, constrói uma narrativa pautada em estereótipos. Aqui temos o olhar do colonizado e o olhar do colonizador. Sobre isso, se sobressai o olha do homem branco sob a ótica da mulher negra.

Para compreendermos essa relação de memória, busca-se evidenciar na trajetória literária de Bernardo Guimarães, as condições de produção, as formações discursivas e os efeitos raciais e de gênero que influenciou na sua visibilidade.

Bernardo Joaquim da Silva Guimarães nasceu em 1825, em Minas Gerais, na cidade de Ouro Preto, onde também veio a falecer no ano de 1884. Formou-se em Direto, foi jornalista, professor e literato. Escreveu O ermitão de Muquém (1869), O seminarista e $O$ garimpeiro (ambos publicado em 1872). Seu romance $A$ escrava Isaura, publicado em 1875, foi um dos grandes best-sellers de seu tempo, recebeu elogios inclusive de D. Pedro II, tendo surgido em um momento político e social no qual a campanha abolicionista estava no seu auge.

A sociedade brasileira, apesar de aclamar a produção de Firmina na segunda metade do século XIX, logo foi esquecida e silenciada por mais de 100 anos. Bernardo Guimarães recebeu duras críticas a respeito dos seus escritos, mas continuou e continua sendo aclamado pelo mundo das letras.

De acordo com os críticos, a produção literária de Bernardo Guimarães apresentava uma linguagem simples e convencional. A exemplo disso, Lobato apud Bosi (2015, p. 142) diz:

Lê-lo é ir para o mato, para a roça, mas uma roça adjetivada por menina do Sião, onde os prados são amenos, os vergéis floridos, os rios caudalosos, as matas viridentes, os pícaros altíssimos, os sabiás sonorosos, as rolinhas meigas. [...] não existe nele o vinco energético da impressão pessoal. [...] Bernardo falsifica o nosso mato.

Seu romance $A$ escrava Isaura possui, nas suas linhas, pretensões abolicionistas. Seu enredo apresentado nos folhetins da época, cheio de personagens unidimensionais - o bom é sempre bom e o mau é sempre mau aborda personagens negros de forma implícita, maquiando a situação escravista no Brasil. A protagonista do romance é Isaura, escrava branca dotada dos melhores 
sentimentos, pura de coração e com uma educação exemplar. No entanto, seu senhor e homem com caráter negativo, Leôncio, persegue-a em toda a narrativa.

O romance de Bernardo Guimarães evidencia as questões raciais de uma forma simplória, destacando sempre a escrava branca, notando-se aí uma tentativa de embranquecimento do perfil da mulher negra, e também, que a personagem principal mesmo sendo escrava, seu perfil não é construído com base em estereótipos, pois possui a cor branca. Diferentemente de Maria Firmina dos Reis, que ousa em escrever para o negro e para a mulher e sobre eles, uma narrativa fiel ao contexto em que ela estava inserida, sob o olhar de uma mulher preta e pobre que é afetada pelo seu lugar social.

A escrava Isaura já foi adaptada várias vezes para a televisão brasileira ${ }^{5}$, sempre reprisando, mostrando o regime escravista sobre o olhar do colonizador, fato que contribuiu para a construção do racismo estrutural que já é algo naturalizado. Enquanto Maria Firmina dos Reis, permanece caminhando em passos lentos, através de pesquisadores que se interessam pelo seu discurso e buscam o fim da censura dos seus textos.

As trajetórias intelectuais aqui analisadas servem como referenciação para que se possa compreender a circulação e a cristalização de sentidos, discursos e sujeitos, e também, a memória discursiva. Cada elemento histórico, literário, cada falha, equívoco, permitiu-nos compreender as causas desse "silenciamento" e, consequentemente, apagamento histórico.

\section{CONSIDERAÇÕES (NÃO) FINAIS}

Pesquisar a trajetória literária de Maria Firmina dos Reis, pelo viés da AD, é tratar o sujeito feminino negro, a situação em que ele está inserido e a circulação de sentidos. Ao mesmo tempo, é analisar o discurso desse sujeito, que vai além do significado e do significante, sujeito este, que produz dizeres em um determinado contexto sócio-histórico e é afetado pelo real da língua e pelo real da história, na constituição de significados.

\footnotetext{
${ }^{5}$ A primeira vez, exibida em 100 capítulos, nos anos de 1976 e 1977, pela Rede Globo, no horário das 18 horas.

A segunda vez, exibida em 167 capítulos, nos anos de 2004 e 2005, pela TV Record, no horário das 19 horas.
}

Cadernos Cajuína, V. 4, N. 1, 2019, p.208- 231.

ISSN: 2448-0916 
A análise teve o intuito de evidenciar o "silenciamento" da mulher negra na literatura, as condições de produção, os efeitos de sentidos que afetaram a naturalização do apagamento desse sujeito ideológico. Sobre isso, é importante demostrar as constituições de sentidos, os efeitos raciais e de gênero que influenciaram a invisibilidade desse sujeito.

A análise do "silenciamento" da voz feminina negra dentro da literatura mostra como as condições de produção, a memória discursiva, os efeitos de sentidos, as relações de força e o esquecimento influenciaram nesse apagamento. Firmina está inscrita em um período em que a mulher é vítima da opressão social, ou seja, é inferiorizada em todas as esferas sociais em relação ao homem. O sujeito em questão é construído pelo simbólico, pela materialidade de elementos ideológicos.

O interesse pela Literatura, na perspectiva da $A D^{6}$, possibilitou evidenciar a historicidade da língua, atentando-se para a materialidade da língua no discurso literário na pluralidade de sentidos que (re) significam. A escritora contribuiu assiduamente para a literatura no Brasil. Mesmo assim, ainda não é evidenciada por historiadores literários, mesmo sendo pioneira em diversos aspectos.

A literatura tem uma influência direta na construção da identidade de mulheres negras, visto que esse sujeito sempre fora descrito de maneira submissa, inferior e hipersexualizada por escritores, na sua maioria brancos. Devido a isso, nos dias atuais, esses estereótipos construídos e naturalizados permeiam o imaginário social. Firmina, mulher, negra e pobre, traz em suas narrativas, a ressignificação da mulher e do negro, causando um estranhamento social.

A escritora faz uma abordagem dos ideais abolicionistas em seus textos, mostrando o sistema escravista, sob uma perspectiva jamais abordada, dá voz à mulher e ao negro nas suas narrativas. Maria Firmina foi uma mulher à frente do seu tempo, mas, apesar de ser aclamada no meio dos literatos, suas obras caíram no esquecimento.

Hoje, existe uma parcela significativa de pesquisadores que buscam tratar das obras, dos discursos, dos significados que trazem a obra de Firmina, um grande avanço para literatura e para as mulheres negras que estão sendo representadas no mundo das letras.

\footnotetext{
${ }^{6}$ As autoras, ou individual, ou em parceria com outros pesquisadores, têm outros trabalhos, enveredando-se por essa proposta de análise do discurso literário, a saber: Rêgo (2016); Ribeiro; Rêgo; Lima (2018) e Lima; Rêgo (2018).
} 
Contudo, tendo em vista a trajetória intelectual analisada, concluímos que expor sua opinião no cenário em que se encontrava foi uma tarefa difícil para a autora, que ousou em tratar da escravidão em seus textos. Assim, ser mulher, negra e usar do seu lugar de fala para proferir dizeres carregados de sentidos, significados e de memória, foi e continua sendo uma tarefa difícil.

Dessa forma, é evidente que o machismo e o racismo são elementos que provocaram o desaparecimento de Maria Firmina dos Reis das prateleiras literárias. Esses dois fatores são, portanto, "acontecimentos" que contribuíram para a pouca representatividade de escritoras negras na literatura nacional, bem como no meio histórico e na mídia.

\section{REFERÊNCIAS}

BOSI, Alfredo. História concisa da literatura brasileira. São Paulo: Cultrix, 2015.

COURTINE, J.J. O discurso inatingível: marxismo e linguística (1965-1985). Trad. Heloisa Monteiro Rosário. Cadernos de Tradução, Porto Alegre, n. 6, 1999.

DIAS, Gonçalves. I - Juca Pirama. Os timbiras. Outros Poemas. São Paulo: Martin Claret, 2002.

DURÃO, José de Santa Rita. Caramuru: poema épico do descobrimento da Bahia. São Paulo: Martin Claret, 2003.

FOUCAULT, M. A ordem do discurso. São Paulo: Loyola, 2014.

. L' impossible prison, recherches sur le systeme pénitentiaire au XIX siècle. Paris: Ed. du Seuil, 1980.

LIMA, Francisco Renato; BORGES, Vanessa Raquel Soares. Identidade e representação letrada da mulher negra nordestina: folheando Úrsula, de Maria Firmina dos Reis. In: Anais do II Colóquio Internacional Literatura e Gênero: relações entre gênero, alteridade e poder. Teresina: FUESPI/UESPI, 2014. v. 1. p. 113.

. Discursos de letramento na construção identitária da mulher negra nordestina em Úrsula, de Maria Firmina dos Reis. Todas as Musas: Revista de Literatura e das Múltiplas Linguagens da Arte (ONLINE), v. 2, p. 201-209, 2018.

; RÊGO, Safira Ravenne da Cunha. Discursos, contradiscursos e memórias homoafetivas em espaços escolares: uma leitura histórico-discursiva de O Ateneu, de Raul Pompéia. In: Francisco Renato Lima; Marcos Helam Alves da Silva. (Org.). 
Linguagem em (con) texto: discurso e práticas cotidianas.Teresina: EDUFPI, 2018, p. $91-120$.

LOBO, Luiza. Crítica sem juízo. Rio de Janeiro: Francisco Alves, 1993.

LOPES, M. Folha de São Paulo: da produção de sentidos acerca da Guerra do Iraque. São Carlos: Pedro e João Editores, 2009.

MORAIS FILHO, José Nascimento. Maria Firmina: fragmentos de uma vida. São Luis: COCSN, 1975.

NUNES, J.H. O discurso documental na História das Ideias Linguísticas e o caso dos dicionários. Revista Alfa, v. 52, n.1, 2008.

ORLANDI, E. Discurso e texto: formulação e circulação dos sentidos. 4. ed. Campinas: Pontes, 2012.

Análise do discurso: princípios e procedimentos. Campinas: Pontes, 2007. 47, 1995.

Efeitos do verbal sobre o não verbal. Campinas, Revista Rua, n. 1, p. 35-

REIS, Maria Firmina dos. Úrsula: romance; A escrava: conto. 6. ed. Belo Horizonte: Editora PUC Minas, 2017.

RÊGO, Safira Ravenne da Cunha. Teodoro Bicanca, de Renato Castelo Branco: da produção de sentidos e da construção da imagem do homem nordestino. 2016. 88 f. Dissertação (Mestrado em Letras - Estudos de Linguagem) - Centro de Ciências Humanas e Letras. Universidade Federal do Piauí, Teresina, 2016.

RIBEIRO, Nathalie de Jesus Maria; RÊGO, Safira Ravenne da Cunha; LIMA, Francisco Renato. Uma análise discursiva das condições de produção e estereótipos da mulher negra em 'O Cortiço', de Aluísio Azevedo. Revista Ininga, v. 5, p. 51-69, 2018.

TELLES, Norma. Encantações: escritoras e tradição literária no Brasil, século XIX. 1987. 531 f. Tese (Doutorado em Ciências Sociais) - Faculdade de Ciências Sociais. Pontifícia Universidade Católica de São Paulo, São Paulo, 1987. 